- - - - - - - -

\section{$\square$}

Встановлено вплив умов електролізу на склад сплаву $\mathrm{Ni}-\mathrm{Fe}$, електроосадженого із метилсульфонатного електроліту. Показано, що натрій сахаринат істотно не впливає на склад сплаву при густині струму вище 2 А/дм ${ }^{2}$. Встановлено, що натрій сахаринат сприяе підвищенню мікротвердості $i$ зниженню внутрішніх напружень $і$ коерцитивної сили покриттів. Проаналізовано залежність досліджених властивостей сплаву $\mathrm{Ni}-\mathrm{Fe}$ від структуpu осадy

Ключові слова: електроосадження, сплав $\mathrm{Ni}-\mathrm{Fe}$, натрій сахаринат, магнітні властивості, внутрішні напруження, мікротвердість, метилсульфонатний електроліт

Установлено влияние условий электролиза на состав сплава $\mathrm{Ni}$ $\mathrm{Fe}$, электроосажденного из метансульфонатного электролита. Показано, что сахаринат натрия существенно не влияет на состав сплава при плотности тока выше 2 А/дм ${ }^{2}$. Установлено, что сахаринат натрия способствует повышению микротвердости и снижению внутренних напряжений и коэрцитивной силь покрытий. Проанализирована зависимость исследованных свойств сплава $\mathrm{Ni}-\mathrm{Fe}$ от структуры осадка

Ключевые слова: электроосаждение, сплав $\mathrm{Ni}-\mathrm{Fe}$, сахаринат натрия, магнитные свойства, внутренние напряжения, микротвердость, метансульфонатный электролит

\title{
RESEARCH INTO COMPOSITION AND PROPERTIES OF THE Ni-Fe ELECTROLYTIC ALLOY
}

\section{Y. Sknar \\ $\mathrm{PhD}$, Associate Professor}

Department of Electrochemical and Environmental Technologies**

E-mail: yuriy.sknar@gmail.com

I. S k n a r

$\mathrm{PhD}$, Associate Professor*

E-mail: juventa2011@gmail.com

A. Cherem y s inova PhD, Associate Professor*

E-mail: Anna_Sokol_@i.ua

I. Yermolenko $\mathrm{PhD} * * *$

E-mail: kirilesha72@yandex.ua

A. Karakurkchi $\mathrm{PhD}$, Head of Laboratory*** E-mail: anyutikukr@gmail.com

V. Mizi n

PhD, Associate Professor* E-mail: miz.in.@ya.ru

V.Proskurina $\mathrm{PhD}$, Assistant Department of General and Inorganic Chemistry**** E-mail: voproskurina@gmail.com

Y. S a c h a nova $\mathbf{a} * *$

E-mail: organick@ukr.net *Department of Processes, Devices and

General Chemical Technology**

**Ukrainian State University of Chemical Technology Gagarina ave., 8, Dnipro, Ukraine, 49005 $* * *$ Scientific-research laboratory**** $\star * * *$ National Technical University "Kharkiv Polytechnic Institute" Kyrpychova str., 2, Kharkiv, Ukraine, 61002

\section{Introduction}

Contemporary level of technical development makes it possible to create the nano-dimensional objects, which possess special physical-chemical and mechanical properties. This opens up new possibilities in such high-technological spheres of production as electronics and aerospace industries, in instrument manufacturing and power engineering. One of the techniques, which make it possible to synthesize the nano-structured and nano-dimensional films, is the electrodeposition of metals. The variation of technologi- cal parameters and composition of the electrolyte ensures controlled influence on the process of electrosynthesis of coatings and obtaining precipitation with the assigned properties.

It is possible to considerably extend the range of functional characteristics of metallic coatings during electrodeposition of alloys with different component and quantitative composition [1,2]. The alloying of base metal with one or several components leads to a cardinal change in the specific properties of the obtained alloy [3, 4]. Thus it is possible to obtain magnetically hard and magnetically soft materials, 
wear-resistant and corrosion-resistant coatings, galvanic precipitations with high electrocatalytic activity and antifriction coatings.

The alloy of nickel with iron is a multifunctional electrolytic alloy. Depending on the specified requirements, the $\mathrm{Ni}-\mathrm{Fe}$ films can serve as a magnetic material, the electro-catalyst, protective-decorative or wear-resistant coating. Properties of the $\mathrm{Ni}-\mathrm{Fe}$ precipitations are determined by the composition and crystalline structure. The modification of the structure of precipitations at the nano-dimensional level leads to a substantial change in the structurally dependent properties of coatings. This aspect underlies the electrochemical synthesis of alloys with the assigned properties.

Thus, the targeted formation of the Ni-Fe alloys with the predicted functional characteristics requires the establishment of the influence of electrodeposition conditions on the structure and properties of the obtained coatings.

\section{Literature review and problem statement}

The process of the electrodeposition of $\mathrm{Ni}-\mathrm{Fe}$ alloy has been intensively investigated for a long period. The undiminishing interest in these coatings is caused by the combination of such useful properties as low thermal-expansion coefficient, high corrosion resistance, properties of a magnetically soft material. Magnetic properties of the $\mathrm{Ni}-\mathrm{Fe}$ alloy are widely needed in the microelectronic industry. Permalloy, which contains $20 \%$ of iron, plays the key role in contemporary electronic nano-devices $[5,6]$ and in the so-called magnonics [7]. The influence of the conditions of electrolysis on the composition and magnetic saturation of the $\mathrm{Ni}-\mathrm{Fe}$ thin films is examined in [8]. It was established in [9] that the identical magnetic susceptibility of thin skins and nano-wires of the $\mathrm{Ni}-\mathrm{Fe}$ alloy corresponds to different composition of the alloys whose structure differs. A change in $\mathrm{pH}$ of the electrolyte of the alloy deposition affects magnetic characteristics of the obtained coatings [10]. It is shown that an increase in $\mathrm{pH}$ from 2.1 to 4.3 leads to a decrease in the magnitude of magnetic saturation, while the values of coercive force pass the minimum at $\mathrm{pH}$ 2.9. [11] examined a possibility of the modification of magnetic and mechanical properties of the $\mathrm{Ni}-\mathrm{Fe}$ alloys by changing the phase composition during thermal treatment of coatings.

The Ni-Fe alloy manifests electrocatalytic activity relative to the hydrogen evolution reaction. It is shown in [12] that $\mathrm{Ni}-\mathrm{Fe}$ is a better catalyst for the decomposition of water in the alkaline medium than the components that form the alloy. Electrocatalytic activity of the $\mathrm{Ni}-\mathrm{Fe}$ alloy is established as well during hydrogen synthesis in the acid medium [13]. The composition of sulfate electrolyte for the electrodeposition of the nano-crystalline alloy of $\mathrm{Ni}-\mathrm{Fe}$ is optimized in [14], manifesting electrocatalytic activity in the processes of hydrogen and oxygen evolution in the $\mathrm{KOH}$ solution. The nano-structured dendritic coatings with the $\mathrm{Ni}-\mathrm{Fe}$ alloy are proposed in [15] to use as the electrocatalytic material during oxygen evolution from the alkaline electrolyte. It is demonstrated that the highly ordered structure and the developed surface of such materials ensures significant catalytic activity in the process of the electrosynthesis of oxygen.

Nickel-iron coatings are characterized by the improved mechanical properties, which depend on the features of precipitation structure [16]. The structure and mechanical properties of the electrodeposited $\mathrm{Ni}-\mathrm{Fe}$ alloys are predetermined by many factors. It is shown in [17] that the phase composition of alloy depends on the parameters of electrolysis, in particular on the magnitude of current density. The latter influences intensity of hydrogen evolution reaction that proceeds in parallel. A decrease in current output contributes to the formation of $\gamma$-phase with the smaller content of iron in the alloy. Special attention is paid to the fact the high values of microhardness and internal stresses of the $\mathrm{Ni}-\mathrm{Fe}$ precipitations are predetermined by the existence of structure that matches the $\gamma$-phase [17].

The use of special organic additives is one of the techniques to act on the structure and properties of the precipitated coating. A decrease in the size of crystallites and an increase in the microhardness of coatings occur during introduction of saccharin to the deposition electrolyte of the $\mathrm{Ni}-\mathrm{Fe}$ alloy [18]. The values of microhardness of such coatings amount to $656 \mathrm{~kg} / \mathrm{cm}^{2}$. Saccharin is used in the sulfate and chloride deposition electrolytes of the $\mathrm{Ni}-\mathrm{Fe}$ alloy for reducing the internal stresses of precipitations [9, 11]. Saccharin was introduced in [19] to the sulfate electrolyte for obtaining smooth precipitations with low internal stresses. [20] demonstrated a possibility of obtaining the Ni-Fe precipitations of significant thickness from the sulfate electrolyte that contains $1 \mathrm{~g} / \mathrm{l}$ of saccharin. It is also possible, in the presence of saccharin, to apply ultrathin magnetic films with a constant composition of the alloy [21].

As the analysis of scientific literature data reveals, the most common deposition electrolytes of the $\mathrm{Ni}-\mathrm{Fe}$ alloys are the sulfate electrolytes. At the same time, the composition, structure and properties of galvanic precipitations depend on the character of the utilized electrolyte. It is shown in [22, 23 ] that the methanesulfonate electrolytes possess valuable features. The coatings, precipitated from such electrolytes, are characterized by high mechanical and magnetic properties [24, 25]. Methanesulfonate electrolytes are the new and insufficiently studied ones. Interesting results, obtained when studying the electrodeposition of metals and alloys from such electrolytes, predetermined the choice of subject of the present research. It appears expedient to establish the influence of sodium saccharinate on the composition, structure and properties of the $\mathrm{Ni}-\mathrm{Fe}$ precipitations obtained from the methanesulfonate electrolyte.

\section{Research goal and objectives}

The goal of present study is to establish the character of influence of sodium saccharinate on the composition and properties of the $\mathrm{Ni}-\mathrm{Fe}$ alloy, obtained from the methanesulfonate electrolyte. This will make it possible to develop new technologies for the application of unstressed, solid and magnetic coatings with the $\mathrm{Ni}-\mathrm{Fe}$ alloy, ensuring improved functional characteristics of articles.

To accomplish the set goal, the following tasks have been set:

- to establish the influence of the composition of electrolyte and parameters of electrolysis on the composition of the electrodeposited $\mathrm{Ni}-\mathrm{Fe}$ alloy, and to reveal a degree of action of sodium saccharinate on the content of iron in the alloy;

- to determine the effect of sodium saccharinate on the properties of the electrolytic Ni-Fe precipitations and to establish the dependence of coating properties on the structural changes, caused by organic additive. 


\section{Materials and methods for examining the composition, structure and properties of the coatings with the $\mathrm{Ni}-\mathrm{Fe}$ alloy}

\section{1. Composition of electrolytes and methods for} determining the content of components in the electrolyte and the $\mathrm{Ni}-\mathrm{Fe}$ alloy

Composition of the deposition electrolyte of the $\mathrm{Ni}-\mathrm{Fe}$ alloy: $1.00 \mathrm{M} \mathrm{Ni}\left(\mathrm{CH}_{3} \mathrm{SO}_{3}\right)_{2}+0.30 \mathrm{M} \mathrm{NaCl}+0,70 \mathrm{M} \mathrm{H}_{3} \mathrm{BO}_{3}+$ $+0.02 \mathrm{M} \mathrm{C}_{6} \mathrm{H}_{8} \mathrm{O}_{6}+\mathrm{X} \mathrm{M} \mathrm{Fe}\left(\mathrm{CH}_{3} \mathrm{SO}_{3}\right)_{2}$, where $X=0.03 ; 0.05$; $0.08 ; 0.09 ; 0.11$. We used sodium saccharinate as a special organic additive. Temperature of the electrolysis is $T=333 \mathrm{~K}$, current density is $i=0.1-7.0 \mathrm{~A} / \mathrm{dm}^{2}$, pH 3 .

We measured concentration of nickel(II) ions in the electrolyte using complexometric method. Equivalent point was determined by titration, applying murexide as the indicator. When determining the concentration of nickel(II) ions in the presence of iron(II) ions in the electrolyte, the titration was conducted in the presence of tartaric acid.

We measured the concentration of iron(II) ions in the presence of nickel(II) ions in the electrolytes and the content of iron in the $\mathrm{Ni}-\mathrm{Fe}$ alloys using a photocolorimetric method applying the photocolorimeter KFK-2-UKhL 4.2 (Russia).

The solutions of salts of nickel(II) and thiocyanate complex of iron(III) have different coloring; therefore, it is possible to isolate a region of the spectrum in which the light absorption by the solution of thiocyanate of iron(III) is large while the light absorption by the solution of nickel(II) salt is insignificant. At such a wavelength, optical density of the solution will be determined almost entirely by the iron concentration. In order to select the optimum light filter, we measured optical density of the solutions of nickel(II) sulfate and thiocyanate complex of iron(III) with different light filters. The light filter, which corresponds to a wavelength of $490 \mathrm{~nm}$, is optimal.

Hydrogen $\mathrm{pH}$ index was measured using a glass electrode of the brand ESK-10601/7 (Belarus) in a set with the universal ionomer EV-74 (Belarus).

\section{2. Methods for examining the structure and proper-} ties of coatings with the Ni-Fe alloy

The internal stresses of nickel-iron coatings were determined by the method of the flexible cathode [25]. Equation for calculating the internal stresses $\sigma(\mathrm{MPa})$ takes the form:

$$
\sigma=\frac{E_{c} d_{c}\left(d_{c}+d_{d}\right) z}{3 l^{2} d_{d}},
$$

where $E_{c}$ is the modulus of elasticity of cathode plate, $\mathrm{MPa} ; d_{c}$ is the thickness of cathode, $\mathrm{m} ; d_{d}$ is the thickness of precipitation, $\mathrm{m} ; l$ is the length of the working part of cathode, $\mathrm{m} ; z$ is the deflection of the end of cathode from initial position, $\mathrm{m}$.

The structure of electroplatings was studied using the $\mathrm{X}$-ray diffractometer DRON-3 in the monochromatized Cu$\mathrm{K} \alpha$-emission. Calculation of the crystallite dimensions was conducted by the Scherrer formula:

$$
L=\frac{k \lambda}{\beta \cos \theta}
$$

where $\lambda$ is the wavelength of X-ray radiation; $\beta$ is the halfwidth of the diffraction line of the sample; $k$ is the shape factor $(k=0.940) ; \theta$ is the diffraction angle.
Microhardness by Vickers was measured using the instrument PMT-3 (Russia) at load $P=100 \mathrm{~g}$ and thickness of the coating $25 \mu \mathrm{m}$. The value of microhardness was determined by formula [25]:

$$
H=\frac{1854 P}{l^{2}},
$$

where $l$ is the length of diagonal of the diamond pyramid indentation, $\mu \mathrm{m}$.

We mesured magnetic parameters of the $\mathrm{Ni}-\mathrm{Fe}$ electroplating using a magnetometer with a vibrating sample and stationary measuring coils.

Microphotographs of the surface of coatings were obtained using the electron raster microscope-microanalyzer REMMA-102-02 (Ukraine).

\section{Results of examining the influence of sodium saccharinate on the composition and properties of coatings with the $\mathrm{Ni}-\mathrm{Fe}$ alloy}

Composition of the $\mathrm{Ni}-\mathrm{Fe}$ alloy depends on the content of salts of the alloy-forming components in the electrolyte and conditions of electrodeposition. An increase in the concentration of iron(II) ions in the solution at a constant concentration of nickel(II) ions naturally leads to an increase in the content of iron in the alloy (Fig. 1). Deposition current density affects the composition of alloy in a complex way. An increase in the current density to $1 \mathrm{~A} / \mathrm{dm}^{2}$ leads to an increase in the content of iron in the alloy. Further change in the current density towards larger values contributes to reducing the share of iron in the obtained precipitations. Probably, diffusion limitations for the ions of iron(II) become essential in the region of high current densities. This can lead to a certain reduction in the relative contribution of the current of electric reduction of iron(II) ions to the total current of the alloy deposition.

The greatest practical interest is demonstrated in the $\mathrm{Ni}-\mathrm{Fe}$ alloys that contain about $20 \%$ of iron. Such alloys are used as the magnetically soft films, protective-decorative and wear-resistant coatings. Given this, we obtained precipitations of similar composition in the further studies. The content of iron(II) ions in the electrolyte in this case equalled $0.08 \mathrm{~mol} / \mathrm{l}$.

The influence of sodium saccharinate on the composition of the $\mathrm{Ni}-\mathrm{Fe}$ alloy, deposited from such electrolyte at different current densities, is shown in Fig. 2. As experimental data reveal, in the presence of sodium saccharinate in the electrolyte at current density $1 \mathrm{~A} / \mathrm{dm}^{2}$, a coating with the smaller content of iron is precipitated. However, at a current density of $2 \mathrm{~A} / \mathrm{dm}^{2}$ and larger, the influence of additive on the composition of alloy is insignificant. Apparently, in this case, the examined additive influences the kinetics of electrodeposition of nickel and iron to alloy in equal degree.

Thus, the use of sodium saccharinate is not a complicating factor when applying the alloys with assigned composition. It is obvious that the ratio of metals in the alloy under the conditions of experiment is mainly determined by the concentration of ions in the alloy-forming metals in the electrolyte. 


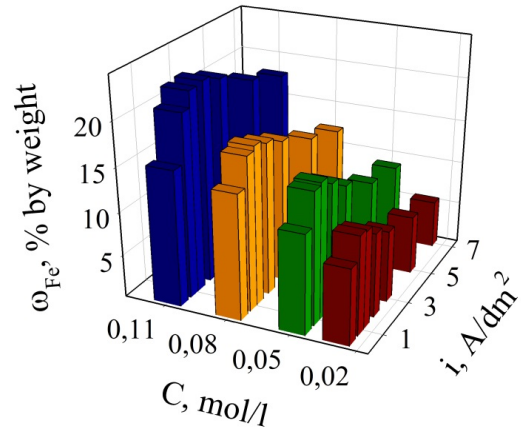

Fig. 1. Influence of the concentration of iron(II) ions in electrolyte and current density on the content of iron in the $\mathrm{Ni}-\mathrm{Fe}$ alloys

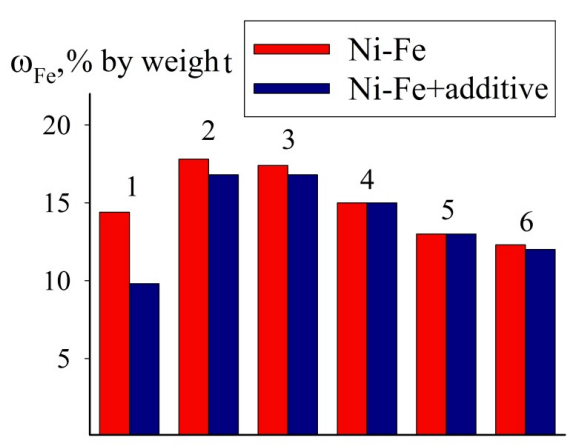

Fig. 2. Dependence of composition of the $\mathrm{Ni}-\mathrm{Fe}$ alloy, obtained at $X=0.08$ in the presence of $6 \mathrm{mmol} / \mathrm{I}$ of sodium saccharinate and without the additive, on current density, A/dm²: $1-0.25 ; 2-1 ; 3-2 ; 4-4 ; 5-6 ; 6-7$

The use of sodium saccharinate during electrodeposition of the $\mathrm{Ni}-\mathrm{Fe}$ alloy from the methanesulfonate electrolyte is predetermined by the need for improving the mechanical properties of coatings. Precipitations obtained without organic additives are characterized by high internal stresses. This leads to the splitting of coatings and flaking from the base. Introduction of sodium saccharinate into the electrolyte contributes to a decrease in the internal tensile stresses. Fig. 3 shows that with an increase in the concentration of additive in the electrolyte, internal stresses of the obtained precipitations change symbatically. In the presence of $6 \mathrm{mmol} / \mathrm{l}$ of sodium saccharinate it is possible to precipitate practically unstressed coatings.

The effect of current density on the internal stresses manifests itself only at small concentrations of the additive. In this case, at high values of current density, a reduction in the internal stresses is observed. This effect cannot be linked to the action of sodium saccharinate. Since the examined substance is an anionic additive, shift of potential towards a more negative region must lead to a reduction in the adsorption of the additive. Consequently, the effectiveness of the action of sodium saccharinate on the internal stresses of precipitation should decrease. Apparently, reduction in the internal stresses with an increase in current density is caused by a change in the composition of alloy.

Introduction of sodium saccharinate into the electrolyte leads to an increase in the microhardness of coatings with the $\mathrm{Ni}-\mathrm{Fe}$ alloy (Fig. 4). With an increase in the current density the microhardness is somewhat reduced.
This can be linked to two factors. With an increase in the current density, the composition of alloy changes towards a decrease in the content of iron. Furthermore, because of reduction in the adsorption at the cathodic surface, the effect of additive on the structure of precipitations decreases.

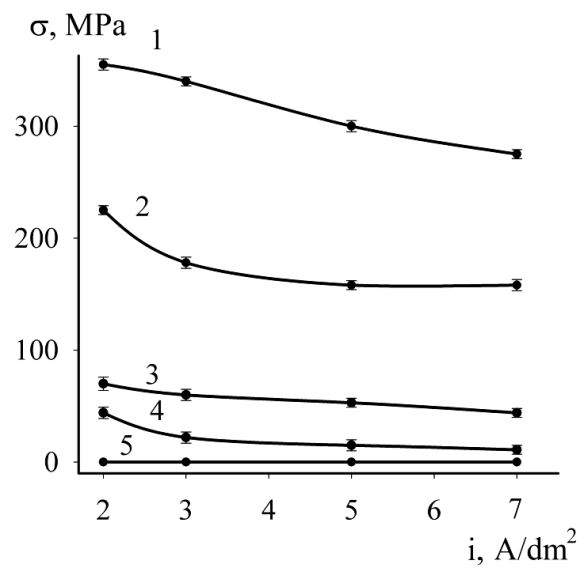

Fig. 3. Effect of the precipitation current density on the internal stresses of the $\mathrm{Ni}-\mathrm{Fe}$ alloy, obtained at $X=0.08$ in the presence of sodium saccharinate, $\mathrm{mmol} / \mathrm{l}$ : $1-0.8 ; 2-1.2 ; 3-2.0 ; 4-3.0 ; 5-6.0$

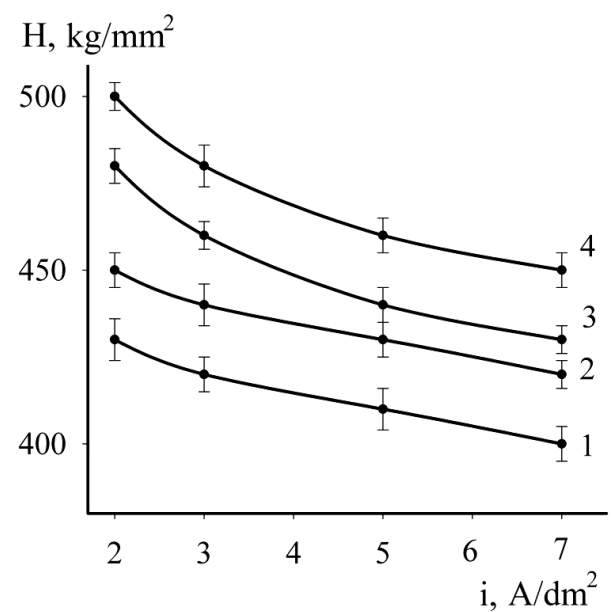

Fig. 4. Effect of the precipitation current density on microhardness of the $\mathrm{Ni}-\mathrm{Fe}$ alloy, obtained at $X=0.08$ in the presence of sodium saccharinate, $\mathrm{mmol} / \mathrm{l}$ : $1-0.8 ; 2-2.0 ; 3-3.0 ; 4-6.0$

In order to investigate magnetic parameters of the $\mathrm{Ni}-$ Fe precipitations, we received magnetic hysteresis loops (Fig. 5). The coating, precipitated from the electrolyte that does not contain organic additive, is characterized by a quite high value of the coercive force, equal to $14 \mathrm{E}$. Introduction of sodium saccharinate into the electrolyte leads to considerable reduction in the coercive force whose magnitude reached $4 \mathrm{E}$. Remanent magnetization of the samples in this case does not change.

Reduction of the magnitude of coercive force of the $\mathrm{Ni}-\mathrm{Fe}$ precipitation in the presence of sodium saccharinate is a positive effect. This is caused by the fact that such films are mainly used as the low-coercive magnetically soft materials. 


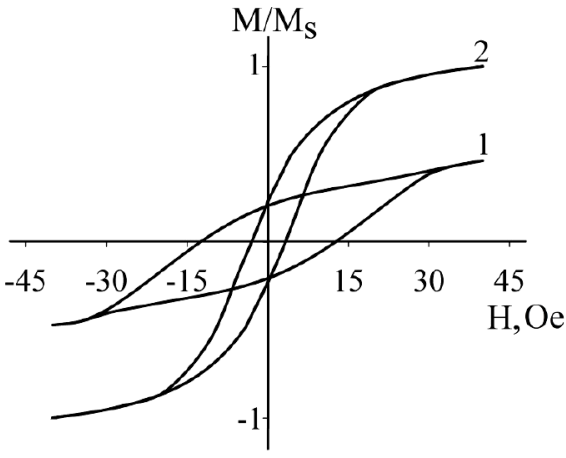

Fig. 5. Magnetic hysteresis loops of the $\mathrm{Ni}-\mathrm{Fe}$ precipitations, obtained at $X=0.08 \mathrm{M}, i=2 \mathrm{~A} / \mathrm{dm}^{2}$ in the presence of sodium saccharinate, $\mathrm{mmol} / \mathrm{l}: 1-0,2-6$

\section{Discussion of results of examining the influence of sodium saccharinate on the composition, structure and properties of coatings with the $\mathrm{Ni}-\mathrm{Fe}$ alloy}

The experimental data obtained testify to the fact that sodium saccharinate weakly influences a composition of the $\mathrm{Ni}-\mathrm{Fe}$ alloy, precipitated from the methanesulfonate electrolyte. At the same time, effect of this organic additive on the properties of coatings is rather significant. Since all the investigated properties are structurally sensitive, then the action of additive on the properties of coatings should be identified with a change in the structure of precipitations.

The increased microhardness of coatings with the $\mathrm{Ni}-\mathrm{Fe}$ alloy when compared to nickel is predetermined by a considerable grain refining. Fig. 6 shows that the morphology of the $\mathrm{Ni}-\mathrm{Fe}$ precipitation differs from that for nickel. Surface of the alloy is characterized by the clearly expressed micro-crystallinity. The size of crystallites of the $\mathrm{Ni}-\mathrm{Fe}$ precipitations, obtained in the presence of sodium saccharinate, decreases with an increase in the concentration of additive (Fig. 7). This should obviously lead to an increase in the microhardness of coatings, which is actually observed in the experiment.

The influence of sodium saccharinate on the structure of the $\mathrm{Ni}-\mathrm{Fe}$ precipitations is linked to the fact that, when adsorbed at the surface of cathode, the additive changes conditions for the electrocrystallization. In addition, sodium saccharinate is partially decomposed on the cathode. Decomposition products in this case fall into the precipitation. A decrease in the size of grains of the $\mathrm{Ni}-\mathrm{Fe}$ precipitations and the presence of impurities in the crystal lattice of coatings results in the elevated microhardness of samples.

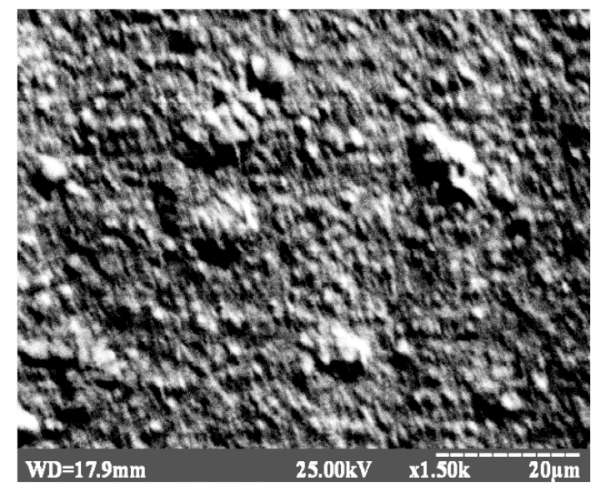

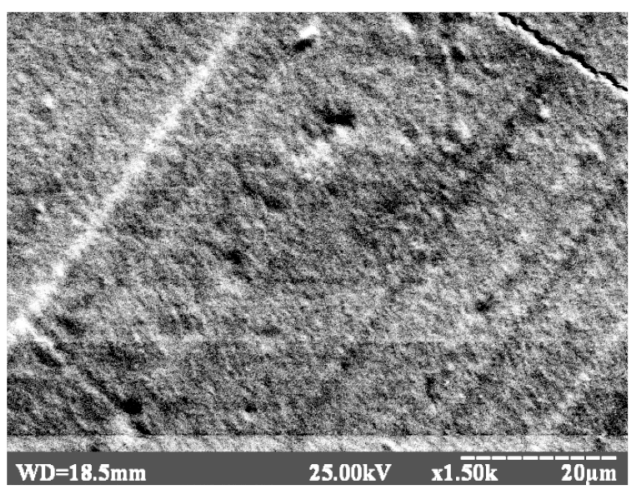

Fig. 6. Surface morphology of the precipitations: $a-$ nickel; $b$ - nickel-iron

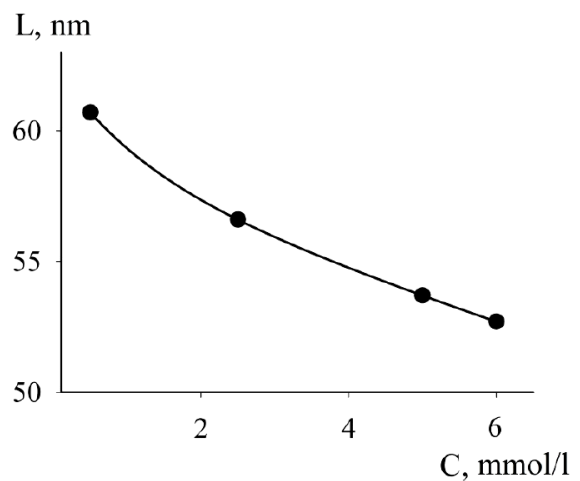

Fig. 7. Dependence of the size of crystallites of the $\mathrm{Ni}-\mathrm{Fe}$ alloy on the concentration of sodium saccharinate in the electrolyte. The content of iron ions in the electrolyte is $0.08 \mathrm{~mol} / \mathrm{l}$, precipitation current density is $2 \mathrm{~A} / \mathrm{dm}^{2}$

The presence of defects and changes in the structure of nickel, alloyed by iron, is predetermined by the fact that nickel and iron coprecipitate in the form of a solid solution, the parameters of crystal lattice of components of which are different. The parameter of crystal lattice of the obtained $\mathrm{Ni}-\mathrm{Fe}$ alloy composes $0.35513 \mathrm{~nm}$, which differs somewhat from the value that corresponds to the face-centered cubic structure of nickel $(0.35170 \mathrm{~nm})$. Distortions in the structure lead to the occurrence of high internal stresses in the $\mathrm{Ni}-\mathrm{Fe}$ alloy.

Introduction of sodium saccharinate into the electrolyte contributes to a reduction in the internal tensile stresses This is mainly connected with the introduction of decomposition products of the additive to a precipitation. Reduction in the internal stresses affects magnetic properties of precipitations. The lower the internal stresses, the less the coercive force of the alloy. This creates a possibility of employing such alloys as the shields of electromagnetic radiation. Furthermore, the obtained films are required for the creation of filters, phase inverters and gates in SHF equipment, magnetic circuits, pole pieces.

\section{Conclusions}

1. We investigated dependence of the composition of the $\mathrm{Ni}-\mathrm{Fe}$ alloy on the concentration of iron(II) ions in the methanesulfonate electrolyte and on the precipitation current density. It is established that the content of iron in the alloy grows with an increase in the concentration of iron(II) ions in the electrolyte. The dependence of the composition of alloy on the current density passes the maximum at current density $1 \mathrm{~A} / \mathrm{dm}^{2}$. Introduction of sodium saccharinate into the electrolyte leads to a reduction in the share of iron in the alloy at precipitation current density to $2 \mathrm{~A} / \mathrm{dm}^{2}$. We did not observe any essential influence of the additive on the composition of alloy in the region of large values of current density.

2. It is established that the introduction of sodium saccha- 
rinate into the methanesulfonate electrolyte of the $\mathrm{Ni}-\mathrm{Fe}$ alloy deposition contributes to an increase in the microhardness of precipitations. An increase in the concentration of additive in the electrolyte leads to the growth of the values of microhardness and reduction in the internal stresses of coatings. The $\mathrm{Ni}-\mathrm{Fe}$ alloy, obtained in the presence of sodium saccharinate, is characterized by the lowered values of coercive force. It is shown that the investigated properties of the $\mathrm{Ni}-\mathrm{Fe}$ precipitations are determined by the structure of coatings. Organic additive is adsorbed at the cathodic surface and changes conditions for the electrocrystallization of alloy. A decrease in the size of precipitation grains and inclusion of decomposition products of the additive in coating predetermine an increase in the microhardness of coatings. Reduction in the internal stresses as a result of sodium saccharinate decomposition products entering the precipitation enables a decrease in the coercive force of the $\mathrm{Ni}-\mathrm{Fe}$ films.

\section{References}

1. Karakurkchi, A. V. Electrodeposition of iron-molybdenum-tungsten coatings from citrate electrolytes [Text] / A. V. Karakurkchi, M. V. Ved', N. D. Sakhnenko, I. Yu. Yermolenko // Russian Journal of Applied Chemistry. - 2015. - Vol. 88, Issue 11. - P. 1860 -1869. doi: 10.1134/s1070427215011018x

2. Yar-Mukhamedova, G. Iron binary and ternary coatings with molybdenum and tungsten [Text] / G. Yar-Mukhamedova, M. Ved, N. Sakhnenko, A. Karakurkchi, I. Yermolenko // Applied Surface Science. - 2016. - Vol. 383. - P. 346-352. doi: 10.1016/j.apsusc.2016.04.046

3. Danilov, F. I. Ni-Co alloy coatings obtained from methanesulfonate electrolytes [Text] / F. I. Danilov, I. G. Tkach, I. V. Sknar, Yu. E. Sknar // Protection of Metals and Physical Chemistry of Surfaces. - 2014. - Vol. 50, Issue 5. - P. 639-642. doi: 10.1134/ s2070205114050062

4. Karakurkchi, A. V. Functional properties of multicomponent galvanic alloys of iron with molybdenum and tungsten [Text] / A. V. Karakurkchi // Functional materials. - 2015. - Vol. 22, Issue 2. - P. 181-187. doi: 10.15407/fm22.02.181

5. Donolato, M. Size-dependent effects in exchange-biased planar Hall effect sensor crosses [Text] / M. Donolato, B. T. Dalslet, C. D. Damsgaard, K. Gunnarsson, C. S. Jacobsen, P. Svedlindh, M. F. Hansen // Journal of Applied Physics. - 2011. - Vol. 109, Issue 6. - P. 064511. doi: 10.1063/1.3561364

6. McNeil, R. P. G. Localized Magnetic Fields in Arbitrary Directions Using Patterned Nanomagnets [Text] / R. P. G. McNeil, R. J. Schneble, M. Kataoka, C. J. B. Ford, T. Kasama, R. E. Dunin-Borkowski et. al. // Nano Letters. - 2010. - Vol. 10, Issue 5. P. 1549-1553. doi: 10.1021/n1902949v

7. Wang, Z. K. Nanostructured Magnonic Crystals with Size-Tunable Bandgaps [Text] / Z. K. Wang, V. L. Zhang, H. S. Lim, S. C. Ng, M. H. Kuok, S. Jain, A. O. Adeyeye // ACS Nano. - 2010. - Vol. 4, Issue 2. - P. 643-648. doi: 10.1021/nn901171u

8. Shorowordi, K. M. Effect of Ni/Fe ratio of electrolyte salts on the magnetic property of electrodeposited Fe-Ni alloy [Text] / K. M. Shorowordi, M. Moniruzzaman, M. F. N. Taufique, A. Azam // Surface Engineering and Applied Electrochemistry. - 2017. Vol. 53, Issue 1. - P. 52-58. doi: 10.3103/s1068375517010124

9. Rousse, C. Electrodeposition of thin films and nanowires Ni-Fe alloys, study of their magnetic susceptibility [Text] / C. Rousse, P. Fricoteaux // Journal of Materials Science. - 2011. - Vol. 46, Issue 48. - P. 6046-6053. doi: 10.1007/s10853-011-5566-9

10. $\mathrm{Su}, \mathrm{X}$. Influence of $\mathrm{pH}$ and bath composition on properties of $\mathrm{Ni}-\mathrm{Fe}$ alloy films synthesized by electrodeposition [Text] / X. Su, C. Qiang // Bulletin of Materials Science. - 2012. - Vol. 35, Issue 2. - P. 1083-189. doi: 10.1007/s12034-012-0284-8

11. Tabakovic, I. Properties of Ni1-xFex $(0.1<x<0.9)$ and Invar $(x=0.64)$ alloys obtained by electrodeposition [Text] / I. Tabakovic, V. Inturi, J. Thurn, M. Kief // Electrochimica Acta. - 2010. - Vol. 55, Issue 22. - P. 6749-6754. doi: 10.1016/j.electacta.2010.05.095

12. Solmaz, R. Electrochemical deposition and characterization of NiFe coatings as electrocatalytic materials for alkaline water electrolysis [Text] / R. Solmaz, G. Kardas // Electrochimica Acta. - 2009. - Vol. 54, Issue 14. - P. 3726-3734. doi: 10.1016/j.electacta.2009.01.064

13. Navarro-Flores, E. Characterization of $\mathrm{Ni}, \mathrm{NiMo}, \mathrm{NiW}$ and $\mathrm{NiFe}$ electroactive coatings as electrocatalysts for hydrogen evolution in an acidic medium [Text] / E. Navarro-Flores, Z. Chong, S. Omanovic // Journal of Molecular Catalysis A: Chemical. - 2005. Vol. 226, Issue 2. - P. 179-197. doi: 10.1016/j.molcata.2004.10.029

14. Ullal, Y. Electrodeposition and electro-catalytic study of nanocrystalline Ni-Fe alloy [Text] / Y. Ullal, A. C. Hegde // International Journal of Hydrogen Energy. - 2014. - Vol. 39, Issue 20. - P. 10485-10492. doi: 10.1016/j.ijhydene.2014.05.016

15. Kim, K. H. Preparation of dendritic NiFe films by electrodeposition for oxygen evolution [Text] / K. H. Kim, J. Y. Zheng, W. Shin, Y. S. Kang // RSC Advances. - 2012. - Vol. 2, Issue 11. - P. 4759. doi: 10.1039/c2ra20241g

16. Li, H. Mechanical behaviors of as-deposited and annealed nanostructured Ni-Fe alloys [Text] / H. Li, F. Jiang, S. Ni, L. Li, G. Sha, X. Liao et. al. // Scripta Materialia. - 2011. - Vol. 65, Issue 1. - P. 1-4. doi: 10.1016/j.scriptamat.2011.03.029

17. Vicenzo, A. Structure and Mechanical Properties of Electrodeposited Nanocrystalline Ni-Fe Alloys [Text] / A. Vicenzo // Journal of the Electrochemical Society. - 2013. - Vol. 160, Issue 11. - P. D570-D577. doi: 10.1149/2.109311jes

18. Yu, J. Effects of saccharin on microstructure and property of electro-deposited Ni-Fe alloys [Text] / J. Yu, M. Wang, Q. Li, J. Yang, L. Liu // Transactions of Nonferrous Metals Society of China. - 2009. - Vol. 19, Issue 4. - P. 805-809. doi: 10.1016/s10036326(08)60354-4

19. Neurohr, K. Near-substrate composition depth profile of direct current-plated and pulse-plated Fe-Ni alloys [Text] / K. Neurohr, A. Csik, K. Vad, G. Molnar, I. Bakonyi, L. Peter // Electrochimica Acta. - 2013. - Vol. 103. - P. 179-187. doi: 10.1016/j.electacta.2013.04.063 
20. Torabinejad, V. Electrodeposition of Ni-Fe alloys, composites, and nano coatings-A review [Text] / V. Torabinejad, M. Aliofkhazraei, S. Assareh, M. H. Allahyarzadeh, A. S. Rouhaghdam // Journal of Alloys and Compounds. - 2017. - Vol. 691. - P. 841-859. doi: 10.1016/j.jallcom.2016.08.329

21. Fazli, S. Effect of plating time on electrodeposition of thick nanocrystalline permalloy foils [Text] / S. Fazli, M. E. Bahrololoom // Transactions of the IMF. - 2016. - Vol. 94, Issue 2. - P. 92-98. doi: 10.1080/00202967.2015.1122918

22. Sekar, R. Effect of sulphonic acids on electrodeposition of nickel and its structural and corrosion behaviour [Text] / R. Sekar, S. Jayakrishnan // Transactions of the IMF. - 2012. - Vol. 90, Issue 6. - P. 324-329. doi: 10.1179/0020296712z.00000000032

23. Danilov, F. I. Electroplating of Ni-Fe alloys from methanesulfonate electrolytes [Text] / F. I. Danilov, I. V. Sknar, Yu. E. Sknar // Russian Journal of Electrochemistry. - 2014. - Vol. 50, Issue 3. - P. 293-296. doi: 10.1134/s1023193514030045

24. Sknar, Yu. E. Influence of Methylsulfonate Anions on the Structure of Electrolytic Cobalt Coatings [Text] / Yu. E. Sknar, N. V. Amirulloeva, I. V. Sknar, F. I. Danylov // Materials Science. - 2016. - Vol. 52, Issue 3. - P. 396-401. doi: 10.1007/s11003-016-9970-9

25. Danilov, F. I. Structure and properties of Ni-Co alloys electrodeposited from methanesulfonate electrolytes [Text] / F. I. Danilov, V. N. Samofalov, I. V. Sknar, Yu. E. Sknar, A. S. Baskevich, I. G. Tkach // Protection of Metals and Physical Chemistry of Surfaces. 2015. - Vol. 51, Issue 5. - P. 812-816. doi: 10.1134/s2070205115050068

Досліджено інгібуючі властивості відомих антискалантів - оксиетиледендифосфонової та нітрилотриметилфосфонової кислот в нейтральному водному середовищі в різних температурних режимах. Визначено здатність йонів d-металів сумісно з фосфоновими кислотами створювати захисний поляризаційний шар на поверхні металу. Встановлено ступінь захисту від корозіі сталі при температурах $30^{\circ} \mathrm{C}$ та $50{ }^{\circ} \mathrm{C}$ з даними композиціями

Ключові слова: корозія, інгібітори, важкі метали, стабілізатори накипоутворення, замкнуті водоциркуляційні системи

$$
\square
$$

Исследованы ингибирующие свойства известных антискалантов - оксиэтиледендифосфоновой и нитрилотриметилфосфоновой кислот в нейтральной водной среде в различных температурных режимах. Определены способности ионов $d$-металлов совместно с фосфоновыми кислотами создавать защитный поляризационный слой на поверхности металла. Установлена степень защиты от коррозии стали при температу$\operatorname{pax} 30{ }^{\circ} \mathrm{C}$ и $50{ }^{\circ} \mathrm{C}$ Әанным композициями

Ключевые слова: коррозия, ингибиторы, тяжелые металлы, стабилизаторы накипеобразования, замкнутые водочиркуляционнные системы

\section{Introduction}

Corrosion causes significant economic losses as it leads to the failure of pipelines, parts of machines, boilers and other metal products. In addition, as a result of this process, equipment breaks down, damaged equipment can lead to an accident, or even a disaster that could affect people and environment. One of the major problems caused by corrosion is the loss of world metal reserves, which in turn leads to significant environmental damage inflicted by steel production.
UDC 547.118: 547.438: 627.257

DOI: $10.15587 / 1729-4061.2017 .106974$

STUDY OF EFFECTIVENESS OF HEAVY METALS IONS AS THE INHIBITORS OF STEEL CORROSION

\author{
T. Shabliy \\ Doctor of Technical Science, Professor* \\ E-mail: dsts1@ukr.net \\ J. Nos a chova \\ $\mathrm{PhD}$, Associate Professor* \\ E-mail: j.nosachova@gmail.com \\ Y. Radovenchik \\ $\mathrm{PhD}$, Associate Professor* \\ E-mail: r.yar@ukr.net \\ V. Ve m ber \\ $\mathrm{PhD}$, Associate Professor * \\ E-mail:vvember@gmail.com \\ National Technical University of Ukraine \\ "Igor Sikorsky Kyiv Polytechnic Institute" \\ Peremohy ave., 37, Kyiv, Ukraine, 03056
}

*Department of Ecology and Technology of Plant Polymers

A large number of industrial enterprises in Ukraine use water from natural sources. A significant amount of water is used by the enterprises of oil refining and machine building industry. Most of the water, about $80 \%$, in these industries is used for reversible cooling systems. The amount of wastewater discharged from these systems to water reservoirs remains significant and makes up about 8-30 \% of the system's volume. This is mostly linked tp the sedimentation in water circulation systems and corrosion processes.

Based on the above, it is possible to say that the problem of protecting metal structures from corrosion processes is 